\title{
PENGGUNAAN TES DIAGNOSTIK THREE-TIER TEST ALASAN TERBUKA UNTUK MENGIDENTIFIKASI MISKONSEPSI LARUTAN PENYANGGA
}

\author{
Febriana Tri Kustiarini, Elfi Susanti VH, dan Agung Nugroho C.S
}

Program Studi Pendidikan Kimia, FKIP, Universitas Sebelas Maret, Surakarta, Indonesia

*Keperluan korespondensi, telp : 08121523622, email : elfisusantivh@staff.uns.ac.id

\begin{abstract}
ABSTRAK
Tujuan penelitian ini adalah untuk mengetahui terjadinya miskonsepsi dan letak miskonsepsi pada siswa kelas XI MIPA SMA Negeri 2 Karanganyar. Miskonsepsi dapat diidentifikasi menggunakan tes diagnostik three-tier test yang didukung dengan hasil observasi proses pembelajaran dan wawancara. Tes diagnostik three-tier tersusun atas 10 soal. Penelitian ini merupakan penelitian kualitatif deskriptif. Penelitian dilakukan di kelas XI MIPA 3, XI MIPA 4 dan XI MIPA 6. Berdasarkan hasil penelitian diketahui bahwa terjadi miskonsepsi pada siswa kelas XI MIPA pada larutan penyangga di SMA Negeri 2 Karanganyar. Persentase miskonsepsi yang dialami siswa yaitu pada submateri sifat larutan penyangga dan pembuatannya (nomor 1: 19,59\%, nomor 2: $25,77 \%$, nomor 3: $13,40 \%$ ), pada submateri menentukan pH larutan penyangga (nomor 4: 77,32\%, nomor 5: 72,16\%, nomor 6: 77,31\%, nomor 7: 56,70\%, nomor 8: $89,69 \%$ ) dan pada submateri contoh larutan penyangga dalam kehidupan sehari-hari (nomor 9: $37,11 \%$ dan nomor 10: 78,35\%). Berdasarkan hasil tersebut maka miskonsepsi terbanyak terjadi pada submateri perhitungan $\mathrm{pH}$ larutan penyangga.
\end{abstract}

Kata Kunci: Larutan penyangga, Miskonsepsi, Three-tier Test

\section{PENDAHULUAN}

Kimia merupakan salah satu mata pelajaran di sekolah menengah atas yang mengandung konsep-konsep yang abstrak. Konsep abstrak tersebut akan menyebabkan siswa memiliki persepsi yang berbeda-beda dalam memahaminya. Guna menjembatani antara fenomologi dan abstraksi, para ahli menggunakan beberaoa representasi yang kemudian dikenal sebagai representasi kimia atau chemical representation [1]. Tiga tingkat representasi dalam kimia tersebut diusulkan oleh Johnston tahun 1982 [2]. Tingkat representasi utersebut meliputi makroskopik, submikroskopik dan simbolik atau ionik.

Tingkat representasi makroskopik ini menjelaskan tentang sebagian besar sifat dari materi yang dapat dilihat oleh mata dan dapat ditemui dalam kehidupan sehari-hari [2]. Johnstone pada tingkat representasi ini menghubungkan antara tingkat deskripsi dan fungsional [3].
Tingkat representasi yang kedua yaitu submikroskopik atau molekular. Tingkat ini menjelaskan tentang tingkat partikulat dari suatu materi yang terdiri dari atom, molekul, ionik dan lain sebagainya [2]. Tingkat representasi ini tidak dapat dilihat langsung oleh mata manusia maupun dengan menggunakan mikroskop optik. Tingkatan ini merupakan tingkatan pemahaman siswa untuk merepresentasikan dan mengkomunikasikan konsep dan ide [3].

Tingkat representasi yang terakhir yaitu simbolik atau ionik. Tingkat representasi ini menjelaskan tentang penggunaan simbol kimia, formula, molaritas, persamaan kimia, serta penggambaran struktur dari molekul, diagram, dan model kimia [2].

Ketiga tingkat representasi tersebut akan mempermudah siswa dalam memahami materi kimia yang abstrak. Apabila siswa sulit dalam memahami materi kimia yang abstrak, maka siswa akan memiliki pemahaman 
yang berbeda-beda. Pemahaman yang berbeda-beda tersebut terkadang berbeda dengan konsep yang sebenarnya. Hal tersebut sering disebut dengan miskonsepsi.

Miskonsepsi yaitu adanya perbedaan antara konsep yang dimiliki oleh seseorang dengan konsep yang dianut oleh para ahli atau pakar [4]. Sumber terjadinya miskonsepsi ini bisa berasal dari beberapa hal seperti materi kimia yang abstrak, faktor guru, proses pembelajaran, maupun dari buku pegangan yang digunakan oleh peserta didik.

Salah satu cara untuk mengetahui terjadinya miskonsepsi pada siswa yaitu dengan tes diagnostik Three-Tier Test. Tes diagnostik Three-Tier Test yaitu suatu tes diagnostik yang tersusun dari tiga tingkatan soal dimana tingkat pertama (one tier) yaitu berupa pilihan ganda biasa atau pertanyaan biasa, tingkat kedua (two tier) berupa pilihan alasan memilih jawaban pada tingkat pertama dan yang terakhir yaitu tingkat ketiga (three tier) yang berupa keyakinan dari siswa berdasarkan jawaban pada tingkat pertama dan kedua [5].

Larutan penyangga merupakan salah satu materi di dalam mata pelajaran kimia. Materi ini sering dianggap sulit oleh peserta didik. Hal tersebut dikarenakan pada materi ini banyak terdapat konsep-konsep yang abstrak. Oleh karena itulah dilakukan penelitian untuk mengetahui terjadinya miskonsepsi pada larutan penyangga pada siswa kelas XI MIPA SMA Negeri 2
Karanganyar dengan menggunakan tes diagnostik Three-tier Test.

\section{METODE PENELITIAN}

Metode yang digunakan dalam penelitian ini adalah metode kualitatif deskriptif. Sampel yang digunakan dalam kelas ini didasarkan pada Stratified random sampling. Sampel yang akan digunakan dalam penelitian ini yaitu terdiri dari tiga kelas yang memiliki ratarata kelas yang tinggi, sedang dan rendah. Kelas tersebut yaitu XI MIPA 3, XI MIPA 4 dan XI MIPA 6. Penentuan kelas tersebut dudasarkan pada PTS (Penilaian Tengah Semster) dan PAS (Penilaian Akhir Semester).

Data didapatkan melalui tes dan nontes. Teknik tes dilakukan dengan pemberian tes tertulis berupa tes diagnostik Three-tier Test. Teknik nontes dilakukan dengan observasi proses pembelajaran dan wawancara kepada siswa. Wawancara dilakukan kepada beberapa siswa yang memiliki keraguan pemahaman berdasarkan tes diagnostik Three-tier test. Keraguan yang dimaksud yaitu hasil tes diagnostik tidak dapat menentukan siswa mengalami miskonsepsi, paham konsep maupun tidak tahu konsep. Selanjutnya dilakukan triangulasi data hasil observasi proses pembelajaran, data hasi tes diagnostik Three-tier Test, dan data hasil wawancara. Kemudian kategori pemahaman siswa dapat dikategorikan sesuai dengan kategori yang terdapat pada Tabel 1.

Tabel 1. Pengelompokan Kategori Pemahaman Siswa

\begin{tabular}{|c|c|c|c|c|}
\hline \multicolumn{3}{|c|}{ Respon siswa } & \multirow[b]{2}{*}{ Kategori } & \multirow[b]{2}{*}{ Singkatan } \\
\hline $\begin{array}{l}\text { (First tier) } \\
\text { Jawaban }\end{array}$ & $\begin{array}{l}\text { (Second tier) } \\
\text { Alasan }\end{array}$ & $\begin{array}{l}\text { (Third tier) } \\
\text { Keyakinan }\end{array}$ & & \\
\hline Benar & Benar & Yakin & Tahu konsep & TK \\
\hline Benar & Benar & Tidak yakin & Tidak tahu konsep (Luccy Guess) & TTK \\
\hline Benar & Salah & Tidak yakin & Tidak tahu konsep & TTK \\
\hline Salah & Benar & Tidak yakin & Tidak tahu konsep & TTK \\
\hline Salah & Salah & Tidak yakin & Tidak tahu konsep & TTK \\
\hline Benar & Salah & Yakin & Miskonsepsi 1 (False Positive) & MK 1 \\
\hline Salah & Benar & Yakin & Miskonsepsi 2 (False negative) & MK 2 \\
\hline Salah & Salah & Yakin & Miskonsepsi 3 & MK 3 \\
\hline
\end{tabular}


Tabel 1 akan digunakan dalam menentukan siswa yang sudah paham dengan konsep, siswa yang tidak tahu konsep maupun siswa yang mengalami miskonsepsi. Akan tetapi, pada penelitian yang dilakukan hanya akan dikategorikan menjadi 3 , yaitu tahu konsep (TK), tidak tahu konsep (TTK) dan miskonsepsi (MK).

\section{HASIL DAN PEMBAHASAN}

Penelitian ini dilakukan di kelas XI MIPA 3, XI MIPA 4 dan XI MIPA 6 SMA Negeri 2 Karanganyar tahun pelajaran 2017/2018 dengan jumlah total siswa sebanyak 97 siswa.

Langkah awal penelitian ini yaitu dengan melakukan observasi proses pembelajara pada tiga kelas tersebut. Berdasarkan observasi proses pembelajaran yang telah dilakukan di dapatkan hasil bahwa ada kemungkinan terjadinya miskonsepsi siswa pada materi larutan penyangga. Kemungkinan terjadinya miskonsepsi tersebut terletak pada submateri perhitungan $\mathrm{pH}$ larutan penyangga. Perhitungan untuk mencari $\left[\mathrm{H}^{+}\right]$yaitu dengan mengalikan tetapan asam lemah dengan perbandingan konsentrasi antara asam lemah dan basa konjugasinya yang berasal dari garam [7]. Setelah itu bisa ditentukan berapa $\mathrm{pH}$ larutan tersebut. Akan tetapi berdasarkan observasi proses pembelajaran guru menjelaskan bahwa penentuan $\left[\mathrm{H}^{+}\right]$ dapat dilakukan dengan menggunakan perbandingan mol bukan perbandingan konsentrasi. Oleh karena itulah siswa tersebut diduga mengalami miskonsepsi. Begitu juga untuk menentukan $\left[\mathrm{OH}^{-}\right]$ pada larutan penyangga basa.

Setelah dilakukan observasi proses pembelajaran dilakukan tes tertulis dengan menggunakan instrumen tes diagnostik Three-Tier Test. Tes tertulis ini tersusu dari 10 soal, dalam setiap soal terdiri dari tiga tingkatan. Tingkatan pertama (tier 1) berupa soal pilihan ganda biasa, tingkat kedua (tier 2) berupa alasan siswa dari tingkat pertama dengan bentuk alasan terbuka dan tingkat terakhir (tier 3) berupa keyakinan siswa atas jawaban pada tier 1 dan tier 2. Berdasarkan tes tertulis yang dilakukan didapatkan adanya kemungkinan terjadinya miskonsepsi pada semua submateri. Kategori pengetahuan siswa berdasarkan tes tertulis dapat dilihat pada Tabel 2.

Tabel 2. Kategori Pengetahuan Siswa Berdasarkan Tes Tertulis Three-tier Test

\begin{tabular}{|c|c|c|c|c|c|c|c|}
\hline \multirow{3}{*}{ Sub Materi } & \multirow{3}{*}{$\begin{array}{l}\text { Nomor } \\
\text { Soal }\end{array}$} & \multicolumn{6}{|c|}{ Kategori Pemahaman } \\
\hline & & \multicolumn{3}{|c|}{ Jumlah Siswa } & \multicolumn{3}{|c|}{ Persentase (\%) } \\
\hline & & TK & TTK & MK & TK & TTK & MK \\
\hline \multirow{3}{*}{$\begin{array}{l}\text { Menjelaskan sifat larutan } \\
\text { penyangga dan pesmbuatannya }\end{array}$} & 1 & 77 & 1 & 19 & 79,38 & 1,03 & 19,59 \\
\hline & 2 & 69 & 3 & 25 & 71,13 & 3,09 & 25,77 \\
\hline & 3 & 66 & 13 & 18 & 68,09 & 13,40 & 18,56 \\
\hline \multirow{5}{*}{$\begin{array}{l}\text { Menentukan pH larutan } \\
\text { penyangga }\end{array}$} & 4 & 17 & 4 & 76 & 17,53 & 4,12 & 78,35 \\
\hline & 5 & 5 & 19 & 73 & 5,15 & 19,59 & 75,26 \\
\hline & 6 & 0 & 17 & 80 & 0,00 & 17,53 & 82,47 \\
\hline & 7 & 0 & 40 & 57 & 0,00 & 41,24 & 58,76 \\
\hline & 8 & 0 & 7 & 90 & 0,00 & 7,22 & 92,78 \\
\hline \multirow{2}{*}{$\begin{array}{l}\text { Menentukan contoh larutan } \\
\text { penyangga dalam kehidupan } \\
\text { sehari-hari }\end{array}$} & 9 & 58 & 2 & 37 & 59,79 & 2,06 & 38,14 \\
\hline & 10 & 14 & 7 & 76 & 14,43 & 7,22 & 78,35 \\
\hline
\end{tabular}

Berdasarkan Tabel 2 dapat dilihat besarnya persentase dan jumlah kategori pengetahuan siswa. Hasil tersebut didasarkan pada analisis jawaban siswa pada Three-tier test sesuai dengan pengelompokan kategori pemahaman siswa pada Tabel 2. Selanjutnya untuk melihat jenis jawaban siswa yang menyebabkan siswa diduga mengalami miskonsepsi dapat dilihat pada Tabel 3 sampai dengan Tabel 12. 
Tabel 3. Jenis Jawaban Siswa yang Diduga Mengalami Miskonsepsi Soal Nomor 1

\begin{tabular}{clc}
\hline No & \multicolumn{1}{c}{ Jawaban Siswa } & Banyak Siswa \\
\hline 1 & $\begin{array}{l}\text { Suatu larutan dapat disebut sebagai larutan penyangga hanya } \\
\text { dilihat dari kemiripan rumusan zat kimianya saja }\end{array}$ & 4 \\
2 & $\begin{array}{l}\text { Larutan penyangga merupakan larutan yang memiliki mol } \\
\text { mula-mula yang sama }\end{array}$ & 8 \\
3 & $\begin{array}{l}\text { Larutan penyangga merupakan larutan yang memiliki mol } \\
\text { yang sama saat kesetimbangan }\end{array}$ & 1 \\
4 & Salah pad tier2 & 5 \\
\hline
\end{tabular}

Soal ini meminta siswa menentukan larutan yang dapat membentuk larutan penyangga. Berdasarkan Tabel 3 dapat dilihat bahwa jawaban siswa yang diduga mengalami miskonsepsi tersebut kurang tepat. Larutan penyangga terdiri dari asam lemah dan basa kuat dengan syarat mol asam lemah yang tersisa atau asam lemah dengan basa konjugasinya dan larutan yang terdiri dari basa lemah dan asam kuat dengan syarat mol basa lemah tersisa atau basa lemah dengan asam konjugasinya [8]. Berdasarkan jawaban tersebut maka dimungkinkan siswa mengalami miskonsepsi.

Tabel 4. Jenis Jawaban Siswa yang Diduga Mengalami Miskonsepsi Soal Nomor 2

\begin{tabular}{|c|c|c|}
\hline No & Jawaban Siswa & Banyak Siswa \\
\hline 1 & $\begin{array}{l}\text { Penambahan sedikit asam, basa dan penetralan } \\
\text { mempengarui } \mathrm{pH} \text { larutan penyangga }\end{array}$ & 22 \\
\hline 2 & $\begin{array}{l}\mathrm{pH} \text { larutan penyangga akan berubah saat ditambah sedikit } \\
\text { asam kuat dan basa kuat dengan selisih yang sama }\end{array}$ & 1 \\
\hline 3 & Salah pada tier 1 tetapi memberikan alasan yang benar & 2 \\
\hline
\end{tabular}

Berdasarkan Tabel 4 dapat dilihat bahwa jawaban ttersebut kurang sesuai, karena larutan penyangga sendiri merupakan larutan yang dapat mempertahankan harga $\mathrm{pH}$. Oleh karena itu apabila larutan penyangga ditambah sedikit asam kuat maka pHnya akan naik sedikit dan apabila ditambah sedikit basa kuat maka pHnya akan turun sedikit [9]. Berdasarkan jawaban siswa tersebut maka dimungkinkan terjadi miskonsepsi pada soal ini.

Tabel 5. Jenis Jawaban Siswa yang Diduga Mengalami Miskonsepsi Soal Nomor 3

\begin{tabular}{llc}
\hline No & \multicolumn{1}{c}{ Jawaban Siswa } & Banyak Siswa \\
\hline 1 & $\begin{array}{l}\text { Suatu larutan dapat hanya dilihat dari kemiripan rumusan zat } \\
\text { kimianya saja tanpa melihat sifat larutan tersebut }\end{array}$ & 7 \\
2 & $\begin{array}{l}\text { Salah satu contoh larutan penyangga terdiri dari asam-basa } \\
\text { lemah }\end{array}$ & 2 \\
3 & $\begin{array}{l}\text { Memberikan alasan yang benar tetapi tidak memilih opsi pada } \\
\text { tier } 1\end{array}$ & 2 \\
4 & $\begin{array}{l}\text { Tidak memberikan alasan dari tier 1 atau benar dalam } \\
\text { menjawab tier 1 tetapi alasan salah }\end{array}$ & 8 \\
\hline
\end{tabular}

Berdasarkan Tabel 5 dapat dilihat bahwa jawaban siswa kurang sesuai. Hal tersebut dikarena dalam menentukan larutan penyangga tidak hanya dilihat dari kemiripan rumusan kimianya saja akan tetapi juga jenis dari larutan tersebut [8]. 
Tabel 6. Jenis Jawaban Siswa yang Diduga Mengalami Miskonsepsi Soal Nomor 4

\begin{tabular}{clc}
\hline No & \multicolumn{1}{c}{ Jawaban Siswa } & Banyak Siswa \\
\hline 1 & Menggunakan perbandingan mol dalam menentukan $\left[\mathrm{H}^{+}\right]$ & 72 \\
2 & Tidak memberikan alasan dari tier 1 & 1 \\
\hline
\end{tabular}

Soal nomor 4 meminta siswa untuk menentukan $\mathrm{pH}$ larutan penyangga asam. Sebelum mencari $\mathrm{pH}$ larutan asam siswa harus menentukan $\left[\mathrm{H}^{+}\right]$terlebih dahulu. Berdasarkan jawaban siswa, siswa tidak menggunakan perbandingan konsentrasi antara asam lemah dan basa konjugasi- nya, akan tetapi menggunakan pernbandingan mol. Seharusnya siswa menggunakan perbandingan konsentrasi dalam menentukan $\left[\mathrm{H}^{+}\right]$[7]. Berdasarkan jawaban pada Tabel 6 maka dimungkinkan terjadinya miskonsepsi pada siswa.

Tabel 7. Jenis Jawaban Siswa yang Diduga Mengalami Miskonsepsi Soal Nomor 5

\begin{tabular}{clc}
\hline No & \multicolumn{1}{c}{ Jawaban Siswa } & Banyak Siswa \\
\hline 1 & Menggunakan perbandingan mol dalam menentukan $\left[\mathrm{OH}^{-}\right]$ & 71 \\
2 & Tidak memberikan alasan dari jawaban tier 1 & 3 \\
\hline
\end{tabular}

Soal pada nomor ini meminta siswa untuk menentukan $\mathrm{pH}$ larutan penyangga basa apabila ditambah dengan sedikit basa kuat. Sebelum menentukan $\mathrm{pH}$ sesudah ditambah, maka siswa harus menentukan besarnya konsentrasi basa lemah dan asam konjugasi sebelum dan sesudah ditambah sedikit basa kuat
[9]. Akan tetapi, berdasarkan jawaban siswa kebanyakan siswa menggunakan mol sesudah dan sebelum ditambah tanpa diubah menjadi konsentrasi. Berdasarkan hal tersebut maka dimungkinkan terjadinya miskonsepsi pada siswa.

Tabel 8. Jenis Jawaban Siswa yang Diduga Mengalami Miskonsepsi Soal Nomor 6

\begin{tabular}{clc}
\hline No & \multicolumn{1}{c}{ Jawaban Siswa } & Banyak Siswa \\
\hline 1 & $\begin{array}{l}\text { Menggunakan perbandingan mol dalam menentukan }\left[\mathrm{H}^{+}\right] \\
\text {untuk mencari massa garam dari asam lemah }\end{array}$ & 71 \\
2 & $\begin{array}{l}\text { Salah dalam konsep mol (hubungan mol, konsentrasi dan } \\
\text { massa) }\end{array}$ & 4 \\
3 & Tidak memberikan alasan dari jawaban tier 1 & 5 \\
\hline
\end{tabular}

Soal nomor 6 meminta siswa untuk mennetukan massa garam dari asam lemah apaila sudah diketahui $\mathrm{pH}$ dan volume garam yang akan digunakan serta volume dan konsentrasi dari asam lemah. Cara yang digunakan untuk menentukan massa dari garam tersebut yaitu dengan menggunakan rumus $\left[\mathrm{H}^{+}\right]$. Rumus mencari $\left[\mathrm{H}^{+}\right]$yaitu konstanta asam dikalikan dengan perbandingan konsentrasi asam lemah dan basa konjugasinya [7]. Setelah diketahui konsentrasi maka dapat dicari massa dari garam. Akan tetapi, berdasarkan jawaban siswa pada Tabel 8 jawaban siswa kurang sesuai. Oleh karena itu, maka pada soal nomor 6 ini dimungkinkan terjadi miskonsepsi.

Tabel 9. Jenis Jawaban Siswa yang Diduga Mengalami Miskonsepsi Soal Nomor 7

\begin{tabular}{clc}
\hline No & Jawaban Siswa & Banyak Siswa \\
\hline 1 & Menggunakan perbandingan mol dalam menentukan $\left[\mathrm{OH}^{-}\right]$ & 55 \\
2 & Tidak memberikan alasan dari jawaban tier 1 & 2 \\
\hline
\end{tabular}


Soal nomor 7 ini meminta siswa untuk menentukan $\mathrm{pH}$ dari larutan penyangga basa apabila diketahui massa dari garam dan volume yang digunakan serta konsentrasi dan volume dari basa lemah. Langkah yang digunakan untuk mengerjakan soal ini adalah siswa harus mencari terlebih dahulu konsentrasi dari garam yang akan dibuat. Selanjutnya siswa harus menen- tukan $\left[\mathrm{OH}^{-}\right]$dengan menggunakan perbandingan konsentrasi antara basa lemah dan asam konjugasi yang berasal dari garam tersebut [7]. Kemudian siswa dapat menentukan $\mathrm{pH}$ dari larutan penyangga basa tersebut. Berdasarkan Tabel 9 dapat dilihat bahwa jawaban siswa kurang sesuai. Oleh karena itulah maka diduga jawaban siswa tersebut mengalami miskonsepsi.

Tabel 10. Jenis Jawaban Siswa yang Diduga Mengalami Miskonsepsi Soal Nomor 8

\begin{tabular}{clc}
\hline No & Jawaban Siswa & Banyak Siswa \\
\hline 1 & Menggunakan perbandingan mol dalam menentukan $\left[\mathrm{OH}^{-}\right]$ & 86 \\
2 & Tidak memberikan alasan dari jawaban tier 1 & 3 \\
\hline
\end{tabular}

Soal nomor 8 ini meminta siswa menentukan $\mathrm{pH}$ dari larutan penyangga basa setelah ditambah dengan sedikit asam kuat. Langkah untuk menentukan $\mathrm{pH}$ larutan tersebut sebelumnya siswa harus menentukan konsentrasi basa lemah dan asam konjugasi sebelum dan sesudah ditambah dengan sedikit asam kuat. Setelah itu siswa menentukan $\left[\mathrm{OH}^{-}\right.$ ] dengan menggunakan konsentrasi basa lemah dan asam konjugasi setelah ditambah dengan sedikit asam kuat. Kemudian yang terakhir siswa dapat menentukan $\mathrm{pH}$ dari larutan tersebut setelah ditambah dengan sedikit asam kuat [9]. Berdasarkan Tabel 10 dapat dilihat bahwa jawaban siswa kurang sesuai, sehingga diduga siswa mengalami miskonsepsi pada nomer ini.

Tabel 11. Jenis Jawaban Siswa yang Diduga Mengalami Miskonsepsi Soal Nomor 9

\begin{tabular}{clc}
\hline No & \multicolumn{1}{c}{ Jawaban Siswa } & Banyak Siswa \\
\hline 1 & $\begin{array}{l}\text { Penyangga karbonat berada di dalam darah dan penyangga } \\
\text { fosfat berada di inti sel }\end{array}$ & 22 \\
2 & $\begin{array}{l}\text { Larutan penyangga fosfat dan karbonat berada di dalam darah } \\
\text { dan di dalam pernafasan }\end{array}$ & 1 \\
3 & $\begin{array}{l}\text { Penyangga fosfat dan penyangga karbonat semua berada di } \\
\text { dalam cairan intrasel }\end{array}$ & 3 \\
4 & Tidak memberikan alasan dari jawaban pada tier 1 & 11 \\
\hline
\end{tabular}

Soal nomor 9 ini meminta siswa untuk menentukan sistem larutan penyangga yang ada di dalam tubuh. Larutan penyangga yang ada di dalam tubuh yaitu larutan penyangga karbonat dan larutan penyangga fosfat. Larutan penyangga karbonat terdapat di luar sel atau lebih tepatnya di dalam darah manusia. Larutan penyangga fosfat terdapat di cairan intrasel [7]. Berdasarkan Tabel 11 dapat dilihat jenis jawaban siswa kurang sesuai, sehingga jawaban siswa itu dimungkinkan mengalami miskonsepsi.

Tabel 12. Jenis Jawaban Siswa yang Diduga Mengalami Miskonsepsi Soal Nomor 10

\begin{tabular}{ccc}
\hline No & \multicolumn{1}{c}{ Jawaban Siswa } & Banyak Siswa \\
\hline 1 & $\begin{array}{l}\text { Larutan penyangga yang dapat mempertahankan } \mathrm{pH} \text { darah } \\
\text { yaitu penyangga fosfat }\end{array}$ & 74 \\
2 & $\begin{array}{l}\text { Penyangga amina ada di dalam darah karena memiliki } \mathrm{pH} \\
\text { yang seimbang antara asam lemah dan basa konjugasinya } \\
\text { dan basa lemah dan asam konjugasinya }\end{array}$ & 1 \\
\hline
\end{tabular}


Soal nomor 10 meminta siswa untuk menentukan larutan penyangga yang dapat mempertahankan $\mathrm{pH}$ darah jika ditambah sedikit asam dan sedikit basa. Jawaban pertanyaan ini yaitu larutan penyangga karbonat [7]. Akan tetapi, berdasarkan Tabel 12 dapat dilihat bahwa jawaban siswa kurang sesuai. Hal tersebut dikarena larutan penyangga yang dapat mempertahankan $\mathrm{pH}$ darah adalah larutan penyangga karbonat. Sedangkan untuk penyangga fosfat adalah larutan penyangga yang berada di dalam cairan intrasel yang marupakan larutan yang mempertankan $\mathrm{pH}$ dalam sistem metabolisme [7]. Oleh karena itulah dimungkinkan siswa mengalami miskonsepsi.

Setelah dilakukan tes tertulis maka dilakukan wawancara kepada siswa yang memiliki jawaban yang meragukan siswa tersebut benar-benar mengalami miskonsepsi atau tidak. Berdasarkan wawancara yang telah dilakukan didapatkan perubahan pada beberapa siswa. Kategori pengetahuan siswa setelah dilakukan wawancara disajikan pada Tabel 13.

Tabel 13. Kategori Pengetahuan Siswa Berdasarkan Tes Tertulis Three-tier Test dan Akhir

\begin{tabular}{|c|c|c|c|c|c|c|c|}
\hline \multirow{3}{*}{ Sub Materi } & \multirow{3}{*}{$\begin{array}{c}\text { Nomor } \\
\text { Soal }\end{array}$} & \multicolumn{6}{|c|}{ Kategori Pemahaman } \\
\hline & & \multicolumn{3}{|c|}{ Persentase Awal(\%) } & \multicolumn{3}{|c|}{ Persentase Akhir(\%) } \\
\hline & & TK & TTK & MK & TK & TTK & MK \\
\hline \multirow{8}{*}{$\begin{array}{l}\text { Menjelaskan sifat larutan } \\
\text { penyangga dan } \\
\text { pembuatannya } \\
\text { Menentukan pH larutan } \\
\text { penyangga }\end{array}$} & 1 & 79,38 & 1,03 & 19,59 & 79,38 & 1,03 & 19,09 \\
\hline & 2 & 71,13 & 3,09 & 25,77 & 71,13 & 3,09 & 25,77 \\
\hline & 3 & 68,09 & 13,40 & 18,56 & 70,10 & 16,49 & 13,40 \\
\hline & 4 & 17,53 & 4,12 & 78,35 & 17,59 & 5,15 & 77,32 \\
\hline & 5 & 5,15 & 19,59 & 75,26 & 5,15 & 22,68 & 72,16 \\
\hline & 6 & 0,00 & 17,53 & 82,47 & 0,00 & 22,68 & 77,31 \\
\hline & 7 & 0,00 & 41,24 & 58,76 & 0,00 & 43,30 & 56,70 \\
\hline & 8 & 0,00 & 7,22 & 92,78 & 0,00 & 10,31 & 89,68 \\
\hline \multirow{2}{*}{$\begin{array}{l}\text { Menentukan contoh } \\
\text { larutan penyangga } \\
\text { dalam kehidupan sehari- } \\
\text { hari }\end{array}$} & 9 & 59,79 & 2,06 & 38,14 & 59,79 & 3,09 & 37,11 \\
\hline & 10 & 14,43 & 7,22 & 78,35 & 14,43 & 7,22 & 78,35 \\
\hline
\end{tabular}

Berdasarkan Tabel 13 dapat dilihat bahwa terdapat beberapa perubahan persentase. Persentase miskonsepsi terbesar pada tiga kelas tersebut terjadi pada submateri perhitungan $\mathrm{pH}$ larutan penyangga yang kemudian submateri contoh larutan penyangga dalam kehidupan sehari-hari dan yang terakhir yaitu pada sifat larutan penyangga dan pembuatannya.

\section{KESIMPULAN}

Berdasarkan penelitian yang te;ah dilakukan dapat disimpulkan bahwa terjadi miskonsepsi pada siswa kelas XI MIPA di SMA Negeri 2 Karanganyar pada materi larutan penyangga. Miskonsepsi terjadi pada semua submateri. Persentase terjadinya miskonsepsi pada setiap submateri yaitu pada submateri sifat larutan penyangga dan pembuatannya (nomor 1: 19,59\%, nomor 2: $25,77 \%$, nomor 3: $13,40 \%$ ), pada submateri menentukan $\mathrm{pH}$ larutan penyangga (nomor 4: $77,32 \%$, nomor 5 : $72,16 \%$, nomor 6: $77,31 \%$, nomor 7 : $56,70 \%$, nomor 8: $89,69 \%$ ) dan pada submateri contoh larutan penyangga dalam kehidupan sehari-hari (nomor 9: $37,11 \%$ dan nomor 10: $78,35 \%$ ). Bedasarkan persentase tersebut dapat dilihat bahwa persentase terjadinya miskonsepsi paling banyak yaitu pada submateri penentuan $\mathrm{pH}$ larutan penyangga, kemudian paa submateri contoh larutan penyangga dalam kehidupan sehari-hari dan yang terakhir pada submateri sifat larutan penyangga dan pembuatannya.

Adapun saran dari peneltian ini yaitu (1) perlu dilakukan penelitian lebih 
lanjut tentang cara mereduksi miskonsepsi yang dialami siswa (2) perlu dilakukan penelitian lebih lanjut untuk menentukan tes diagnostik miskonsepsi yang paling efektif untuk menentukan terjadinya miskonsepsi (3) perlu dilakukan penelitian lebih lanjut pada materi yang lainnya.

\section{UCAPAN TERIMA KASIH}

Penulis mengucapkan terima kasih kepada kepala SMA Negeri 2 Karanganyar ibu Dra. Hj. Suliyastuti, M.M. yang telah memberikan izin dilakukannya penelitian di sekolah, guru kimia ibu Sri Padmini, S.Pd., M.Pd. serta seluruh siswa kelas XI MIPA 3, XI MIPA 4 dan XI MIPA 6 SMA Negeri 2 Karanganyar tahun pelajaran 2017/2018 yang telah membantu dalam menyelesaikan penelitian ini.

\section{DAFTAR RUJUKAN}

[1] Addin, I, Ashadi, \& Masykuri, M. (2016). JKPK.1(2). 58-65.

[2] Jaber, L. Z., \& Boujaoude, S. (2012). IJSE, 34(7), 973-998. https://doi. org/10.1080/09500693.2011.56995 9.
[3] Talanquer, V. (2011). IJSE, 33(2), 179-195. https://doi.org/10.1080/ 09500690903386435.

[4] Yunitasari, W., Susilowati, E, \& Nurhayati, N.D. (2013). JPK. 2(3).182-190.

[5] Syahrul, D. A., \& Setyarsih, W. (2015). JIPF, 04(03), 67-70.

[6] Nikmah, K., \& Suyono. (2015). UNESA JCE, 4(3), 541-550.

[7] Keenan, Kleinfelter, \& Pudjaatmaka, Wood a.Hadyana. (1984). Kimia Untuk Universitas. Jakarta: Erlangga.

[8] Sudarmo, Unggul. (2017). Kimia untuk Sma/Ma Kelas XI. Surakarta: Erlangga.

[9] Brady, James. E. (1990). Kimia Universitas Asas \& Struktur. Jakarta: Binarupa Aksara. 